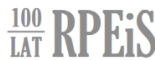

\author{
PAWE€ ŚLIWIŃSKI*, SONIA WOŹNIAK**
}

\section{KOSZTY OBECNOŚCI SPÓŁKI NA RYNKU NEWCONNECT I ICH POSTRZEGANIE PRZEZ EMITENTÓW}

\section{WSTĘP}

Jedną z głównych barier rozwoju małych i średnich przedsiębiorstw (MSP) sa ograniczenia $\mathrm{w}$ dostępie do środków finansowych ${ }^{1}$. Zjawisko niedopasowania popytu na kapitał zgłaszany przez MSP i podaży ze strony instytucji finansowych i rynku kapitałowego jest opisywane w literaturze naukowej jako luka finansowa lub luka kapitałowa ${ }^{2}$. Przez pojęcie luki finansowej (financing gap) rozumie się ograniczony dostęp do finansowania zewnętrznego, zarówno własnego, jak i obcego. Luka kapitałowa (equity gap) oznacza z kolei ograniczone możliwości pozyskania kapitału własnego na rozwój działalności bieżącej i inwestycyjnej.

Jednym ze sposobów niwelowania luki finansowania właścicielskiego jest dostęp małych i średnich przedsiębiorstw do rynku giełdowego, w szczególności do alternatywnego systemu obrotu. Wskazaniem istotnej roli, jaka pełni alternatywny system obrotu w dostępie do kapitału dla małych i średnich przedsiębiorstw, jest rosnąca liczba europejskich rynków alternatywnych. Przykładem takiego rynku jest rynek NewConnect prowadzony przez Giełdę Papierów Wartościowych w Warszawie. Został on stworzony z myśla o małych i średnich przedsiębiorstwach cechujących się wysokim potencjałem wzrostu i chęcią pozyskania kapitału na dalszy rozwój. Zgodnie z założeniem organizatora rynku NewConnect ma niwelować lukę powstałą pomiędzy finansowaniem własnym a kapitałem, który możliwy jest do pozyskania przez spółki zmierzające na ry-

\footnotetext{
* Paweł Śliwiński, Uniwersytet Ekonomiczny w Poznaniu, pawel.sliwinski@ue.poznan.pl, https://orcid.org/0000-0001-8479-3252

** Sonia Woźniak, Uniwersytet Ekonomiczny w Poznaniu, sonia.wozniak@ue.poznan.pl, https://orcid.org/0000-0001-7243-9539

1 Storey (1996); Lopez-de-Silanes, McCahery et al. (2018); Rymarczyk (2019).

2 OECD (2006); Bernat (2015); Woś (2018); Wieczorek-Kosmala, Błach et al. (2020).
} 
nek regulowany ${ }^{3}$. Równolegle $\mathrm{z}$ badaniami nad rola polskiego alternatywnego systemu obrotu w zmniejszaniu luki kapitałowej w sektorze MSP prowadzane sa m.in. prace badawcze dotyczace barier w rozwoju rynku NewConnect ${ }^{4}$, funkcjonowania i rozwoju notowanych na nim spółek ${ }^{5}$ czy efektywności inwestycji $\mathrm{w}$ te podmioty ${ }^{6}$. Badania ankietowe przeprowadzone zarówno wśród polskich ${ }^{7}$, jak i wśród zagranicznych ${ }^{8}$ małych i średnich spółek wskazuja, że niskie koszty bycia spółką publiczną są jednym z najważniejszych czynników sprzyjających rozwojowi rynku kapitałowego dla spółek z sektora MSP9 .

Celem artykułu jest analiza kosztów obecności spółek na NewConnect oraz zbadanie ich postrzegania przez notowanych na tym rynku emitentów. Hipoteza badawczą poddaną weryfikacji w artykule jest hipoteza zakładająca, że koszty obecności spółek na rynku NewConnect sa wysokie z punktu widzenia notowanych na tym rynku spółek. Uzasadnienie postawionej hipotezy związane jest z najwyższą pozycja, jaką nadali ankietowani w przytoczonych badaniach kosztom związanym z byciem spółką giełdową. Jeżeli by tak było, to koszty funkcjonowania spółek w obrocie giełdowym stanowiłyby przeszkodę w rozwoju tego rynku, ponieważ ograniczałyby wykorzystanie rynku kapitałowego do zmniejszania luki kapitałowej.

\section{METODYKA BADANIA I CHARAKTERYSTYKA RESPONDENTÓW}

Weryfikację postawionej hipotezy przeprowadzono z wykorzystaniem badań ankietowych metodą CAWI, przeprowadzonych w okresie od 6 września 2017 do 2 marca 2018 r. wśród spółek notowanych na rynku NewConnect. Ankiety zwrotne otrzymano od 74 spośród notowanych wówczas 407 emitentów NewConnect ${ }^{10}$.

Wśród respondentów najliczniejszą grupa stanowiły małe przedsiębiorstwa - 30, podczas gdy mikro- i średnie przedsiębiorstwa odpowiednio 24 i 18 , 2 spółki nie przekazały danych pozwalających przyporządkować je do właściwej kategorii MSP oraz branży ${ }^{11}$. Najwięcej spośród ankietowanych spółek zade-

${ }^{3}$ Szczepankowski (2010); Kordela (2013); Zygmanowski (2017); Kruk i Sobczak (2019); Gołda, Kowalczyk et al. (2019).

${ }^{4}$ Zygmanowski (2017); Śliwiński, Krawiec, Nowak (2017); Zygmanowski, Śliwiński (2019).

${ }^{5}$ Szczepankowski (2010).

${ }^{6}$ Pastusiak (2010); Kordela (2012); Homa i Mościborska (2016).

7 Śliwiński, Krawiec, Nowak (2017).

${ }^{8}$ WFE (2017).

${ }^{9}$ Niskie koszty bycia spółką giełdową uzyskały w tych badaniach najwyższą notę (średnio 3,3 w skali od 1 do 4 , gdzie 3 to „ważne”, a 4 to „bardzo ważne”) wyprzedzając, takie czynniki, jak: uproszczone obowiązki informacyjne $(3,2)$, zachęty podatkowe dla inwestorów $(3,19)$ czy możliwość szybkiego pozyskania dodatkowego kapitału $(3,18)$.

${ }^{10}$ Przy populacji liczącej 407 spółek NewConnect, 95\% przedziale ufności i akceptowalnym błędzie pomiaru na poziomie $10 \%$, próba badawcza powinna liczyć 74 jednostki. Wynosi zatem tyle samo co liczba poprawnie wypełnionych kwestionariuszy ankiety.

${ }^{11}$ Klasyfikacja respondentów do właściwej kategorii mikro-, małych i średnich przedsiębiorstw została przeprowadzona na podstawie Rozporządzenia Komisji (WE) nr 364/2004 z 25 lutego 2004 r. (Dz. Urz. L 63 28.02.2004). 
biutowało w okresie 2010-2012. Na rynku NewConnect pojawiło się wówczas łacznie 41 respondentów (17 w 2011 i po $12 \mathrm{w}$ latach 2010 i 2012). Natomiast najmniej debiutantów, tylko ośmiu, weszło do polskiego alternatywnego systemu obrotu w okresie 2013-2015 ${ }^{12}$.

Wszyscy respondenci pozyskali w emisjach pierwotnych i wtórnych łącznie 524,6 mln zł, w tym mikroprzedsiębiorstwa: 54,1 mln zł, małe: 248,8 mln zł, a średnie: 204,7 mln zł. Analiza wartości pozyskanego kapitału wskazuje, że najwięcej spółek pozyskało kapitał w przedziale od 1 do $4 \mathrm{mln}$ złotych (29 respondentów). Przedział ten jest najliczniej reprezentowany przez mikroi małe przedsiębiorstwa.

Ankietowane spółki cechowały się dużą dywersyfikacją branżową (sektorowa). Reprezentowały one sektor handlowy (w tym e-handel), usługowy (w tym usługi finansowe), IT i budowlany. Najliczniej była reprezentowana branża usługowa - 37 respondentów. Na kolejnych miejscach uplasował się sektor handlowy (25\%), budowlany (13,9\%) i IT (9,7\%). Próba badawcza cechowała się dużą dywersyfikacją geograficzną. Reprezentowała 13 województw, przy czym większość spółek pochodziła z województw: mazowieckiego (31\%), wielkopolskiego $(17,6 \%)$ i dolnośląskiego $(17,6 \%)$.

\section{KOSZTY ZWIĄZANE Z WEJŚCIEM I OBECNOŚCIĄ SPÓŁKI NA NEWCONNECT}

Ponoszone przez emitentów koszty obecności na alternatywnym rynku akcji można podzielić na koszty, które spółka musi ponieść do momentu upublicznienia (koszty wejścia na rynek NewConnect) oraz koszty, które spółka ponosi, będąc już spółką publiczną (koszty obecności na rynku NewConnect).

\section{Koszty wejścia na NewConnect}

Koszty wejścia na NewConnect zależą m.in. od tego, jaką formę prawną posiada spółka, która podejmuje decyzję dotyczącą upublicznienia. W sytuacji konieczności przekształcenia formy prawnej będą to: (i) koszty związane z przekształceniem formy prawnej oraz koszty właściwe dla spółki akcyjnej, (ii) koszty związane z emisją akcji (dla spółek, które łączą decyzję o debiucie giełdowym z emisją w ramach tzw. IPO), (iii) opłaty związane z notowaniem na NewConnect, (iv) pozostałe koszty związane z debiutem wynikajace z przepisów. W przypadku spółek akcyjnych nie są ponoszone koszty związane z przekształceniem formy prawnej, a koszty właściwe dla spółki akcyjnej były już ponoszone przed decyzją o upublicznieniu. Warto także zaznaczyć, iż mimo że jednym z podstawowych motywów ubiegania się o notowanie na rynku NewConnect jest pozyskanie kapitału na rozwój, nie wszystkie spółki przeprowadzają emisję nowych akcji przed upublicznieniem.

12 W latach 2007-2009 oraz 2016-2018 zadebiutowało, odpowiednio, 13 i 10 spółek. 
Spółka, która zdecydowała się na upublicznienie swoich akcji na NewConnect, musi złożyć wniosek o wprowadzenie akcji na ten rynek. Związana jest z nim opłata z tytułu złożenia tego wniosku, a w przypadku jego pozytywnego rozpatrzenia opłata za wprowadzenie akcji do obrotu giełdowego. Spółka musi również zdematerializować akcje w Krajowym Depozycie Papierów Wartościowych (KDPW). Koszty związane z dematerializacja akcji związane sa z rejestracją akcji w KDPW. Poza tym kosztem emitenci, jak wszyscy uczestnicy KDPW, zobowiązani są do uzyskania z KDPW międzynarodowego kodu LEI, który identyfikuje podmioty prawne działające na rynku kapitałowym. Kolejną opłatą jest wpłata na pokrycie kosztów nadzoru nad rynkiem kapitałowym obliczana corocznie zgodnie z rozporządzeniem Ministra Finansów z 17 grudnia 2019 r. w sprawie opłat na pokrycie kosztów nadzoru nad rynkiem kapitałowym (Dz. U. 2019, poz. 2486). Spółki publiczne w zależności od wysokości swojego kapitału własnego wykazanego w ostatnim rocznym sprawozdaniu finansowym opublikowanym lub przekazanym do publicznej wiadomości na podstawie przepisów ustawy (art. 94a ustawy o ofercie publicznej ${ }^{13}$ ) zobowiązane sa do jej uiszczenia. Opłaty związane z dopuszczeniem akcji do obrotu na NewConnect zebrane zostały w tabeli 1.

Tabela 1

Opłaty związane z debiutem na NewConnect

\begin{tabular}{|c|l|c|}
\hline \multicolumn{2}{|c|}{ GPW } \\
\hline 1 & $\begin{array}{l}\text { Opłata za wprowadzenie do obrotu, w przypadku pierw- } \\
\text { szego wprowadzenia do obrotu akcji danego emitenta }\end{array}$ & $6000 \mathrm{zł}$ \\
\hline 2 & $\begin{array}{l}\text { Opłata za złożenie wniosku o wprowadzenie do obrotu } \\
\text { akcji }\end{array}$ & $1500 \mathrm{zł}$ \\
\hline \multicolumn{3}{|c|}{ KDPW } \\
\hline 1 & Opłata z tytułu rejestracji akcji KNF & $\begin{array}{l}0,01 \% \text { wartości rynkowej akcji } \\
\text { min. 5000 zł - max. 100 000 zł }\end{array}$ \\
\hline 2 & Opłata z tytułu otrzymania kodu LEI & 271 zł \\
\hline \multicolumn{2}{|c|}{} & $\begin{array}{l}\text { Opłata na pokrycie kosztów nadzoru nad rynkiem kapi- } \\
\text { tałowym }\end{array}$ \\
\hline 1 & $1500-30000$ euro \\
\hline
\end{tabular}

Źródło: strony internetowe KNF, KDPW oraz GPW [dostęp: 4.10.2020].

Wprowadzenie akcji emitenta do obrotu giełdowego wymaga współpracy z autoryzowanym doradca oraz biurem maklerskim. Zgodnie z Regulaminem Alternatywnego Systemu Obrotu ${ }^{14}$ autoryzowanym doradca jest „firma inwesty-

${ }^{13}$ Ustawa z 29 lipca 2005 r. o ofercie publicznej i warunkach wprowadzania instrumentów finansowych do zorganizowanego systemu obrotu oraz o spółkach publicznych (Dz. U. 2005, Nr 184, poz. 1539 ze zm.).

14 Regulamin ASO, <https://newconnect.pl/regulacje-prawne>. 
cyjna lub inny podmiot będący spółką prawa handlowego świadczący usługi związane $\mathrm{z}$ obrotem gospodarczym, w tym doradztwo finansowe, doradztwo prawne lub audyt finansowy wpisany na listę prowadzona przez Organizatora Alternatywnego Systemu Obrotu”. Jest to podmiot, któremu organizator ASO przekazał część obowiązków związanych z kontrolą emitentów planujących wejść na rynek NewConnect, przygotowaniem ich do debiutu i wspieraniem w poczattkowym okresie obecności na giełdzie (do trzech lat). Koszty związane ze współpraca z autoryzowanym doradcą do debiutu na rynku NewConnect pokrywaja m.in. doradztwo prawne oraz finansowe, a także, co do zasady, sporządzenie dokumentu informacyjnego stanowiącego istotny koszt przygotowania spółki do debiutu.

Poza współpraca z autoryzowanym doradca debiut giełdowy wymaga zaangażowania domu maklerskiego, który pełni rolę agenta emisji (pośrednika rejestracyjnego), a niekiedy również sponsora emisji. Do zadań agenta emisji należy w szczególności: utworzenie ewidencji osób uprawnionych z papierów wartościowych i prowadzenie jej do czasu zarejestrowania papierów wartościowych w KDPW, pośredniczenie w zawieraniu przez emitenta umowy, której przedmiotem jest rejestracja papierów wartościowych w KDPW, złożenie wniosku o rejestrację papierów wartościowych oraz rozliczenie emisji w KDPW, a także rozksięgowanie akcji na rachunkach maklerskich inwestorów w porozumieniu z emitentem i KDPW. W przypadku nieposiadania przez niektórych inwestorów rachunków papierów wartościowych agent emisji może pełnić także funkcję sponsora emisji, który prowadzi ich ewidencję. Opłata na rzecz agenta/sponsora emisji jest opłatą umowną.

Dla zobrazowania kosztów związanych $\mathrm{z}$ wejściem na NewConnect zestawiono koszty, jakie ponieśli debiutanci ASO w Polsce w latach 2017-2020 w związku z przeprowadzeniem oferty i podwyższeniem kapitału, w tym koszty związane z debiutem na NewConnect oraz koszty przygotowania dokumentu informacyjnego (tab. 2).

\section{Tabela 2}

Koszty sporządzenia dokumentów informacyjnych oraz ogół kosztów związanych z emisją poprzedzającą debiut na NewConnect

\begin{tabular}{|c|c|c|c|c|c|}
\hline \multirow{2}{*}{ Okres } & \multirow{2}{*}{$\begin{array}{l}\text { Liczba } \\
\text { debiutów }\end{array}$} & \multicolumn{3}{|c|}{$\begin{array}{c}\text { Koszty sporządzenia dokumentu } \\
\text { informacyjnego }\end{array}$} & \multirow{2}{*}{$\begin{array}{c}\text { Całość kosztów zwią- } \\
\text { zanych z podwyż- } \\
\text { szeniem kapitału, } \\
\text { w tym z wejściem na } \\
\text { NewConnect } \\
\text { Mediana } \\
\end{array}$} \\
\hline & & Minimum & Maksimum & Mediana & \\
\hline 2017 & 19 & $20000 \mathrm{zł}$ & $640000 \mathrm{zł}$ & $77500 \mathrm{zł}$ & $332500 \mathrm{zł}$ \\
\hline 2018 & 15 & $10000 \mathrm{zł}$ & $200000 \mathrm{zł}$ & $40000 \mathrm{zł}$ & $197295 \mathrm{zł}$ \\
\hline 2019 & 15 & $20000 \mathrm{zł}$ & $200000 \mathrm{zł}$ & $56900 \mathrm{zł}$ & $185000 \mathrm{zł}$ \\
\hline $\begin{array}{c}01-10 \\
2020\end{array}$ & 11 & $40000 \mathrm{zl}$ & $244700 \mathrm{zł}$ & $72404 \mathrm{zł}$ & $209208 \mathrm{zł}$ \\
\hline
\end{tabular}

Źródło: opracowanie własne na podstawie dokumentów informacyjnych spółek debiutujących na NewConnect. 


\section{Koszty obecności na NewConnect}

Koszty obecności spółki na NewConnect dotyczą głównie dwóch aspektów: (i) opłat związanych z notowaniami oraz (ii) kosztów umownych związanych z koniecznościa posiadania autoryzowanego doradcy i animatora rynku. Poza tymi kosztami pojawiają się także inne wydatki, których wprawdzie emitent nie musi ponosić, ale może uważać ich poniesienie za słuszne (np. wynagrodzenie agencji public relations/investor relations).

\subsection{Opłaty związane z notowaniami akcji na NewConnect}

Opłaty związane z notowaniami na NewConnect dotyczą opłat na rzecz organizatora rynku (GPW), depozytariusza papierów wartościowych (KDPW) oraz nadzorcy nad rynkiem kapitałowym (KNF).

Na rzecz GPW pojawia się opłata za notowanie akcji w ASO. W pierwszym roku wynosi ona 1,5 tys. zł, a w kolejnych latach od 3 do 8 tys. zł, w zależności od wartości rynkowej dopuszczonych do obrotu akcji. Również kolejne wprowadzenie do obrotu akcji własnych skutkuje koniecznościa wniesienia na rzecz organizatora rynku opłaty. Opłaty na rzecz KDPW związane sa z występowaniem zdarzeń korporacyjnych, takich jak wypłaty dywidendy czy organizacja walnego zgromadzenia akcjonariuszy. Co rok należy również odnowić ważność kodu LEI. Wpłata na pokrycie kosztów nadzoru nad rynkiem kapitałowym jest coroczna i jej wysokość zależna jest od wysokości kapitału własnego wykazanego w ostatnim rocznym sprawozdaniu finansowym opublikowanym lub przekazanym do publicznej wiadomości na podstawie przepisów ustawy (art. 94a ustawy o ofercie publicznej).

Opłaty na rzecz GPW, KDPW i KNF zebrane zostały w tabeli 3. W przypadku GPW i KDPW uwzględniono coroczne opłaty oraz opłaty dotyczace wprowadzania kolejnych emisji akcji oraz wypłaty dywidendy. Nie uwzględniono z kolei zdarzeń bardzo rzadkich (np. obniżenie wartości nominalnej akcji, scalenie czy unieważnienie akcji).

Tabela 3

Opłaty urzędowe związane z notowaniami akcji po debiucie spółki na NewConnect

\begin{tabular}{|c|l|c|}
\hline \multicolumn{2}{|c|}{ GPW } \\
\hline 1 & $\begin{array}{l}\text { Opłaty w kolejnych latach kalendarzowych noto- } \\
\text { wania akcji danego emitenta (opłata roczna) }\end{array}$ & $\begin{array}{l}\mathbf{0 , 0 2 \%} \text { wartości rynkowej } \\
\text { akcji; min. 3000 zl, max. } \\
8000 \text { zł }\end{array}$ \\
\hline 2 & $\begin{array}{l}\text { Opłata jednorazowa za wprowadzenie do obrotu w przy- } \\
\text { padku kolejnego wprowadzenia do obrotu akcji danego } \\
\text { emitenta }\end{array}$ & $2500 \mathrm{zł}$ \\
\hline 3 & $\begin{array}{l}\text { Opłata za złożenie wniosku o wprowadzenie do obrotu } \\
\text { akcji }\end{array}$ & $1500 \mathrm{zł}$ \\
\hline
\end{tabular}




\begin{tabular}{|c|c|c|}
\hline \multicolumn{3}{|c|}{ KDPW } \\
\hline 1 & $\begin{array}{l}\text { Opłata z tytułu obsługi wypłaty dywidendy, zaliczki na } \\
\text { poczet dywidendy }\end{array}$ & $\begin{array}{l}0,2 \% \text { wartości przekazywanej } \\
\text { kwoty; min. } 1500 \mathrm{zl} \\
\text { max. } 50000 \mathrm{zł}\end{array}$ \\
\hline 2 & $\begin{array}{l}\text { Opłata za udostępnienie emitentowi informacji } \\
\text { o osobach uprawnionych do uczestnictwa w wal- } \\
\text { nym zgromadzeniu (opłata roczna) }\end{array}$ & $2500 \mathrm{zl}$ \\
\hline 3 & Opłata z tytułu rejestracji kolejnej emisji akcji & $\begin{array}{l}\text { 0,01\% wartości rynkowej akcji; } \\
\text { min. } 5000 \mathrm{zł}-\max .100000 \mathrm{zł}\end{array}$ \\
\hline 4 & $\begin{array}{l}\text { Opłata z tytułu utrzymania kodu LEI (opłata } \\
\text { roczna) }\end{array}$ & $261 \mathrm{zl}$ \\
\hline \multicolumn{3}{|c|}{ KNF } \\
\hline 1 & $\begin{array}{l}\text { Opłata na pokrycie kosztów nadzoru nad rynkiem } \\
\text { kapitałowym (opłata roczna) }\end{array}$ & $1500-30000$ euro \\
\hline
\end{tabular}

Źródło: strony internetowe KNF, KDPW oraz GPW [dostęp: 4.10.2020].

\subsection{Koszty umowne związane z koniecznością posiadania autoryzowanego doradcy $i$ animatora rynku}

Niezbędnym warunkiem umożliwiającym notowanie akcji w alternatywnym systemie obrotu jest posiadanie umowy z autoryzowanym doradca oraz pisemnego zobowiązania animatora rynku do animowania papierów wartościowych.

Zgodnie z Regulaminem ASO (par. 18 pkt 2 oraz 3) autoryzowany doradca po debiucie spółki na NewConnect w zakresie współpracy z emitentem jest zobowiązany do współdziałania z nim w zakresie wypełniania obowiązków informacyjnych, monitorowania prawidłowości wypełniania tych obowiązków oraz do bieżącego doradzania emitentowi w zakresie dotyczącym funkcjonowania jego instrumentów finansowych w alternatywnym systemie obrotu. Umowa z autoryzowanym doradca powinna przewidywać wykonywanie przez niego powyższych obowiązków określonych przez okres co najmniej 3 lat od dnia pierwszego notowania instrumentów finansowych danego emitenta w alternatywnym systemie obrotu ${ }^{15}$.

Animatorem rynku jest członek rynku lub inna firma inwestycyjna (wykonująca czynności animatora za pośrednictwem członka rynku), która na podstawie umowy zawartej z GPA w Warszawie jest zobowiązana do wspomagania płynności obrotu instrumentami finansowymi notowanymi na rynku NewCon-

${ }_{15} \mathrm{Na}$ wniosek emitenta organizator ASO może zwolnić go z obowiązku zawarcia umowy z autoryzowanym doradcą w przypadkach określonych Regulaminem ASO (Regulamin ASO, par. 18 pkt 4a). 
nect (Regulamin ASO, par. 20 pkt 1) ${ }^{16}$. Wspomaganie płynności obrotu polega na stałym utrzymaniu przez animatorów rynku ofert w arkuszu zleceń, co pozwala inwestorom na otwarcie lub zamknięcie inwestycji w dowolnym momencie.

Z uwagi na charakter umowny relacji emitentów z autoryzowanymi doradcami oraz animatorami rynku brak publicznie dostępnej informacji dotyczącej kształtowania się opłat dotyczących świadczonych przez nich usług.

\section{Koszty obecności na NewConnect. Badania ankietowe}

W badaniu ankietowym emitenci zostali poproszeni o wskazanie przedziału ponoszonych kosztów obecności na rynku NewConnect (koszty ponoszone na rzecz autoryzowanego doradcy, animatora, opłaty oraz inne, jeżeli występuja). Mieli oni do wyboru trzy przedziały miesięcznych kosztów: (i) poniżej 5 tys. zł, (ii) od 5 do 10 tys. zł, oraz (iii) powyżej 10 tys. zł. Analiza odpowiedzi respondentów notowanych na rynku NewConnect (tab. 4) wskazuje, że najwięcej spółek ponosiło miesięczne koszty w kwocie nieprzekraczajaccej 5 tys. zł (40 emitentów), najmniej zaś powyżej 10 tys. zł (7 emitentów). Koszty w kwocie od 5 do 10 tys. zł zostały wskazane przez 27 emitentów.

Respondenci zostali także poproszeni o wskazanie przedziału miesięcznych kosztów za usługi autoryzowanego doradcy oraz animatora rynku. Analiza odpowiedzi pokazuje, że w momencie badania najwięcej spółek ponosiło koszty za usługi autoryzowanego doradcy w przedziale od 1 do 3 tys. złotych, najmniej zaś od 3 do 5 tys. zł i powyżej 5 tys. zł. W momencie udziału w badaniu 1/3 przedsiębiorców nie korzystała z usług autoryzowanego doradcy. Z kolei miesięczne koszty animatora rynku kształtowały się w większości przypadków w przedziałach: 1000-1500 zł oraz 600-1000 zł (tab. 4).

Tabela 4

Miesięczne koszty obecności na rynku NewConnect

\begin{tabular}{|c|c|c|c|c|c|c|}
\hline & \multicolumn{5}{|c|}{ Miesięczne koszty } & Razem \\
\hline \multirow[t]{2}{*}{$\mathrm{AD}$} & $(0-500] \mathrm{zł}$ & $(500-1000] \mathrm{zł}$ & $(1000-3000] \mathrm{zl}$ & $(3000-5000] \mathrm{zł}$ & $>5000 \mathrm{zł}$ & \\
\hline & 9 & 7 & 26 & 3 & 1 & 46 \\
\hline \multirow[t]{2}{*}{ Animator } & $(0-600] \mathrm{zł}$ & $(600-1000] \mathrm{zl}$ & $(1000-1500] \mathrm{zl}$ & $(1500-2000] \mathrm{zł}$ & $>2000 \mathrm{zł}$ & \\
\hline & 9 & 24 & 30 & 9 & 0 & 72 \\
\hline \multirow{2}{*}{$\begin{array}{l}\text { Koszty } \\
\text { lączne } \\
\text { obecności } \\
\text { na New- } \\
\text { Connect }\end{array}$} & $(0-5000] \mathrm{zl}$ & (5000-10000] & $>10000 \mathrm{zl}$ & & & \\
\hline & 40 & 27 & 7 & & & 74 \\
\hline
\end{tabular}

Źródło: opracowanie własne.

${ }_{16}$ Organizator ASO może postanowić o notowaniu instrumentów finansowych w alternatywnym systemie obrotu bez konieczności spełnienia warunku posiadania umowy zawartej z animatorem w przypadkach określonych Regulaminem (Regulamin ASO, par. 9 pkt 5). 


\section{POSTRZEGANIE MIESIĘCZNYCH KOSZTÓW OBECNOŚCI NA NEWCONNECT}

\section{Ocena miesięcznych kosztów obecności na NewConnect}

Przy ocenie kosztów posłużono się pytaniem jednokrotnego wyboru narzucajaccym następujące odpowiedzi: (i) adekwatne, (ii) zbyt wysokie, (iii) nie mam zdania. Spośród 74 spółek, które udzieliły odpowiedzi na to pytanie, 21 uznało ponoszone koszty za adekwatne, 51 - za wysokie, a 2 respondentów nie miało wyrobionego swojego zdania (tab. 5).

Wśród przedsiębiorców ponoszących opłaty poniżej 5 tys. zł prawie 2/3 (60\%) określiła ich poziom jako za wysoki, a co trzeci jako adekwatny. Również dla większości emitentów, którzy oszacowali koszty obecności rynku giełdowym w przedziale od 5 do 10 tys. zł były one zbyt wysokie (74\% ankietowanych). Z kolei wszyscy emitenci ponoszący koszty powyżej 10 tys. zł. ocenili je jako zbyt wysokie.

Tabela 5

Ocena miesięcznych kosztów obecności na rynku NewConnect

\begin{tabular}{|l|c|c|c|c|}
\hline \multirow{2}{*}{$\begin{array}{c}\text { Koszty obecności } \\
\text { na rynku } \\
\text { NewConnect }\end{array}$} & Adekwatne & Nie mam zdania & Zbyt wysokie & Ogółem \\
\cline { 2 - 5 } & 14 & 2 & 24 & 40 \\
\hline Poniżej $5000 \mathrm{zł}$ & 7 & 0 & 20 & 27 \\
\hline Od 5000 do $10000 \mathrm{zł}$ & 0 & 0 & 7 & 7 \\
\hline Powyżej 10 000 zł & $\mathbf{2 1}$ & $\mathbf{2}$ & $\mathbf{5 1}$ & $\mathbf{7 4}$ \\
\hline SUMA & & & & \\
\hline
\end{tabular}

Źródło: opracowanie własne.

Dane na temat kosztów obecności na rynku NewConnect oraz ich oceny przez emitentów umożliwiają zbadanie korelacji pomiędzy wartością miesięcznych kosztów obecności na giełdzie a ich postrzeganiem. Celem badania jest sprawdzenie, czy wartość miesięcznych kosztów obecności na rynku NewConnect ma związek z ich negatywnym postrzeganiem przez emitentów. Do zweryfikowania związku wykorzystano nieparametryczny współczynnik korelacji rang rho Spearmana ${ }^{17}$. W celu jego przetestowania sformułowano hipotezę zerową $\left(\mathrm{H}_{0}: \rho=0\right.$, brak związku pomiędzy oceną kosztów obecności na NewConnect oraz miesięcznymi kosztami obecności na tym rynku) oraz hipotezę alternatywna ( $\mathrm{H}_{1}: \rho \neq 0$, istnieje taki związek), gdzie $\rho$ oznacza współczynnik korelacji rang rho Spearmana dla populacji generalnej.

17 Szerzej na temat współczynnik korelacji rang rho Spearmana w Aczel, Sounderpandian, (2018). 
Obliczony współczynnik korelacji wyniósł $r s=0,23$ (niski związek), który okazał się istotnie statystyczny na poziomie istotności $\left.p^{*}=0,05\right)$. W związku z powyższym odrzucono hipotezę zerową o braku związku pomiędzy ocena kosztów obecności na NewConnect oraz miesięcznymi kosztami obecności na tym rynku.

Otrzymane wyniki wskazuja, że dla polskich emitentów spadek pozytywnej (wzrost negatywnej) oceny kosztów może być związany ze wzrostem miesięcznych kosztów obecności na giełdzie. Może to oznaczać m.in., że emitenci NewConnect nie sa zadowoleni ze stosunku kosztów bycia spółką giełdową do kwoty pozyskanego kapitału oraz do innych korzyści wynikających z notowania akcji na NewConnect. Wynik może również sugerować, że nie istnieje powiązanie pomiędzy wielkością kosztów związanych z obecnością na rynku NewConnect a oceną współpracy z obsługującymi je podmiotami (autoryzowany doradca, animator rynku, organizator rynku oraz KDPW) z uwagi na niewystępowanie dodatkowych korzyści, które rekompensowałyby zwiększone obciażenia finansowe z tytułu faktu bycia spółką giełdowa.

\section{Postrzeganie miesięcznych kosztów obecności na giełdzie a realizacja motywów upublicznienia spółki}

Wśród ankietowanych spółek 81\% z nich wskazało możliwość pozyskania kapitału jako główny motyw wejścia na NewConnect. W tabeli 6 przedstawiono ocenę kosztów obecności na rynku NewConnect z uwzględnieniem wartości pozyskanego kapitału. Respondenci notowani na rynku NewConnect, którzy pozyskali w ramach emisji pierwotnej i wtórnych kapitał poniżej $1 \mathrm{mln} \mathrm{zl}^{18}$, ponosili miesięczne koszty obecności na giełdzie w przedziałach: poniżej 5 tys. zł (64\% respondentów) i od 5 do 10 tys. zł (36\%). Zdecydowana większość emitentów (86\%) oceniła poniesione przez nich koszty jako zbyt wysokie. Emitenci, którzy pozyskali środki w kwocie od 1 do $4 \mathrm{mln}$ zł, ponosili z reguły koszty poniżej 5 tys. zł (59\%) i od 5 do 10 tys. zł (34\%). Niezależnie od wartości miesięcznych kosztów obecności na giełdzie zostały one ocenione przez większość spółek (59\%) jako zbyt wysokie. Kapitał w kwocie od 4 do $11 \mathrm{mln}$ zł pozyskali przedsiębiorcy, których miesięczne koszty oscylowały poniżej 5 tys. zł (53\% respondentów) i od 5 do 10 tys. zł (47\%). Zdecydowana większość spółek w tej grupie (67\%) oceniła opłaty związane z obecnościa na giełdzie jako zbyt wysokie. Większość ankietowanych, którzy pozyskali w ramach emisji pierwotnej i wtórnych kapitał w przedziałach od 11 do $20 \mathrm{mln}$ zł i powyżej $21 \mathrm{mln}$ zł, poniosło koszty przekraczające 5 tys. zł. Koszty w wysokości poniżej 5 tys. zł poniosło tylko 38\% ankietowanych spółek. W obu grupach $75 \%$ respondentów oceniło poniesione przez nich koszty jako zbyt wysokie.

${ }^{18}$ Wśród respondentów nie było spółek, które nie pozyskały kapitału w ramach emisji pierwotnej lub emisji wtórnych. 
Tabela 6

Ocena kosztów obecności na rynku NewConnect z uwzględnieniem wartości pozyskanego kapitału (liczba emitentów)

\begin{tabular}{|c|c|c|c|c|c|}
\hline & \multicolumn{4}{|c|}{ Koszty obecności na rynku NewConnect } \\
\hline & & $\begin{array}{l}\text { poniżej } \\
5000 \mathrm{zl}\end{array}$ & $\begin{array}{c}\text { od } 5000 \\
\text { do } 10000 \mathrm{zl}\end{array}$ & $\begin{array}{l}\text { powyżej } \\
10000 \mathrm{zl}\end{array}$ & Ogółem \\
\hline \multicolumn{2}{|c|}{$\begin{array}{l}\text { Wartość pozyskanego kapitału } \\
\text { poniżej } 1 \mathrm{mln} \text { zl }\end{array}$} & 9 & 5 & $\mathbf{0}$ & 14 \\
\hline \multirow{3}{*}{$\begin{array}{l}\text { Ocena } \\
\text { kosztów }\end{array}$} & Adekwatne & 1 & 1 & 0 & 2 \\
\hline & Nie mam zdania & 0 & 0 & 0 & 0 \\
\hline & Zbyt wysokie & 8 & 4 & 0 & 12 \\
\hline \multicolumn{2}{|c|}{$\begin{array}{l}\text { Wartość pozyskanego kapitału } \\
\text { od } 1 \text { do } 4 \text { mln zl }\end{array}$} & 17 & 10 & 2 & 29 \\
\hline \multirow{3}{*}{$\begin{array}{l}\text { Ocena } \\
\text { kosztów }\end{array}$} & Adekwatne & 8 & 3 & 0 & 11 \\
\hline & Nie mam zdania & 1 & 0 & 0 & 1 \\
\hline & Zbyt wysokie & 8 & 7 & 2 & 17 \\
\hline \multicolumn{2}{|c|}{$\begin{array}{l}\text { Wartość pozyskanego kapitału } \\
\text { powyżej } 4 \text { do } 11 \mathrm{mln} \text { zl }\end{array}$} & 8 & 7 & 0 & 15 \\
\hline \multirow{3}{*}{$\begin{array}{l}\text { Ocena } \\
\text { kosztów }\end{array}$} & Adekwatne & 3 & 1 & 0 & 4 \\
\hline & Nie mam zdania & 1 & 0 & 0 & 1 \\
\hline & Zbyt wysokie & 4 & 6 & 0 & 10 \\
\hline \multicolumn{2}{|c|}{$\begin{array}{l}\text { Wartość pozyskanego kapitału } \\
\text { powyżej } 11 \text { do } 21 \mathrm{mln} \text { zl }\end{array}$} & 3 & 3 & 2 & 8 \\
\hline \multirow{3}{*}{$\begin{array}{l}\text { Ocena } \\
\text { kosztów }\end{array}$} & Adekwatne & 1 & 1 & 0 & 2 \\
\hline & Nie mam zdania & 0 & 0 & 0 & 0 \\
\hline & Zbyt wysokie & 2 & 2 & 2 & 6 \\
\hline \multicolumn{2}{|c|}{$\begin{array}{l}\text { Wartość pozyskanego kapitału } \\
\text { powyżej } 21 \mathrm{mln} \text { zl }\end{array}$} & 3 & 2 & 3 & 8 \\
\hline \multirow{3}{*}{$\begin{array}{l}\text { Ocena } \\
\text { kosztów }\end{array}$} & Adekwatne & 1 & 1 & 0 & 2 \\
\hline & Nie mam zdania & 0 & 0 & 0 & 0 \\
\hline & Zbyt wysokie & 2 & 1 & 3 & 6 \\
\hline
\end{tabular}

Źródło: opracowanie własne.

Obserwacja postrzegania miesięcznych kosztów obecności na giełdzie przez emitentów z uwzględnieniem wartości pozyskanego w ramach emisji pierwotnej i wtórnych kapitału może wskazywać, że zdaniem respondentów niezależnie od wartości pozyskanego kapitału koszty obecności na rynku NewConnect były uznawane za wysokie. Można jednak zauważyć, że (i) postrzeganie kosztów obecności na giełdzie jest najbardziej negatywne w grupie spółek, które pozyskały najmniej kapitału (poniżej $1 \mathrm{mln}$ złotych), (ii) negatywne postrzeganie kosztów obecności na giełdzie jest wprawdzie mniejsze w grupie spółek, które pozyskały kapitał na rozwój w przedziale od $1 \mathrm{mln}$ do $3 \mathrm{mln}$ zł, ale potem 
nie maleje wraz ze zwiększaniem się kwoty pozyskanego kapitału, (iii) wśród emitentów, którzy pozyskali podobną kwotę kapitału, percepcja kosztów obecności na giełdzie ulega zmianie wraz ze wzrostem wartości kosztów.

Chociaż większość spółek przeprowadzała emisje pierwotne, to pozyskanie kapitału na rozwój nie było jedynym motywem upublicznienia. Spółki wybrały się na parkiet giełdowy w celu zwiększenia swej wiarygodności (51\%) i rozpoznawalności (49\%), a także uzyskania rynkowej wyceny (28\%) i prestiżu spółki giełdowej (41\%). Część spółek myślała o umożliwieniu sprzedaży akcji przez ich właścicieli (12\%), pozyskaniu inwestora strategicznego (11\%) oraz wykorzystaniu upublicznia do konsolidacji branży (8\%). Zestawienie oceny kosztów związanych z obecnością na NewConnect ze stopniem realizacji motywów wejścia na ten rynek uwidacznia związek pomiędzy oceną realizacji motywów wejścia na NewConnect a oceną kosztów obecności na tym rynku (tab. 7). Warto zauważyć, że liczba pozytywnych ocen dotyczących wysokości tych kosztów, a także udział takich ocen w ich całkowitej liczbie, jest największa w przypadku pozytywnej oceny realizacji celów wejścia na rynek giełdowy.

Tabela 7

Ocena kosztów obecności na rynku NewConnect z uwzględnieniem realizacji motywów wejścia na rynek giełdowy (liczba emitentów)

\begin{tabular}{|l|c|c|c|c|}
\hline \multirow{2}{*}{$\begin{array}{c}\text { Ocena realizacji } \\
\text { motywów wejścia } \\
\text { na NewConnect }\end{array}$} & Adekwatne & $\begin{array}{c}\text { Nie mam } \\
\text { zdania }\end{array}$ & Zbyt wysokie & \multirow{2}{*}{ Ogółem } \\
\cline { 2 - 5 } & 15 & 2 & 20 & 37 \\
\hline Tak & 6 & 0 & 28 & 34 \\
\hline Częściowo & 0 & 0 & 2 & 2 \\
\hline Nie & $\mathbf{0}$ & $\mathbf{0}$ & $\mathbf{1}$ & $\mathbf{1}$ \\
\hline SUMA & $\mathbf{2 1}$ & $\mathbf{2}$ & $\mathbf{5 1}$ & $\mathbf{7 4}$ \\
\hline
\end{tabular}

Źródło: opracowanie własne.

\section{Postrzeganie miesięcznych kosztów obecności na giełdzie przez emitentów rynku NewConnect a ocena współpracy z autoryzowanym doradcą, animatorem rynku, GPW oraz KDPW}

Ankietowani przedsiębiorcy zostali również poproszeni o ocenę usług świadczonych przez autoryzowanych doradców oraz animatorów, a także o ocenę współpracy z organizatorem rynku oraz KDPW. W pięciostopniowej skali Likerta odpowiedzi zostały zakodowane za pomoca liczb całkowitych od 1 (bardzo źle) do 5 (bardzo dobrze).

Najwyżej ankietowani ocenili współprace z autoryzowanymi doradcami. Średnia ocena wyniosła 3,7 pkt, jednak charakteryzowała się ona największa zmiennością (odchylenie standardowe wyniosło 1,2 pkt). Z kolei na 3,6 pkt 
oceniono współpracę z KDPW ( $\sigma=0,85)$, a na 3,4 współpracę z GPW $(\sigma=0,95)$. Najniżej emitenci ocenili jakość usług ze strony animatorów rynku (ocena 3,0, $\sigma=1,1)$. Po analizie odpowiedzi dotyczacych oceny współpracy z ww. uczestnikami rynku zbadano, czy istnieje współzależność pomiędzy miesięcznymi kosztami ponoszonymi na rzecz autoryzowanych doradców oraz animatorów, a także kosztami obecności na NewConnect a ocena świadczonych na rzecz emitentów usług. Istnienie istotnego pozytywnego związku mogłoby oznaczać, że wzrost kosztów obecności na giełdzie jest rekompensowany wysoką jakością usług świadczonych przez autoryzowanych doradców i animatorów, a także dobrą współpraca z GPW oraz KDPW.

Do zweryfikowania związku ponownie wykorzystano nieparametryczne testy korelacji rang rho Spearmana. W celu ich przetestowania sformułowano hipotezy zerowe o braku związku pomiędzy wysokością kosztów ponoszonych na rzecz autoryzowanych doradców, animatorów oraz kosztów obecności na NewConnect $\left(\mathrm{H}_{0}: \rho=0\right)$ oraz odpowiednio ocena współpracy z autoryzowanymi doradcami, animatorami, GPW i KDPW oraz hipotezy alternatywne $\left(\mathrm{H}_{1}: \rho \neq 0\right.$, istnieje taki związek). Uzyskane korelacje okazały się bliskie zeru, jednak nieistotne statystycznie na poziomie istotności $p^{*}=0,05$, co pokazuje tabela 8. Można zatem generalnie założyć, że wysokość kosztów związanych z obecnością na NewConnect ponoszonych przez emitentów nie ma istotnego statystycznie odzwierciedlenia w ocenie pracy autoryzowanych doradców, animatorów, GPW oraz KDPW. Niemniej jednak pozytywne korelacje pomiędzy kosztami za usługi autoryzowanych doradców a oceną z nimi współpracy, choć nieistotne statystycznie, mogą wskazywać na akceptację wyższych kosztów w przypadku zadowolenia z jakości świadczonych przez nich usług. Pozytywna ocena może wynikać z potrzeby posiadania wsparcia ze strony autoryzowanego doradcy (w wyniku braku doświadczenia i wiedzy emitenta o funkcjonowaniu w środowisku giełdowym lub braku wydzielonego w strukturze spółki działu zajmującego się realizacją obowiązków giełdowych), świadomości dużego nakładu czasu i pracy przy wypełnianiu obowiązków giełdowych bądź zadowolenia z jakości obsługi ze strony autoryzowanych doradców. Generalnie jednak uzyskane wyniki moga wskazywać, że percepcja kosztów obecności na polskiej giełdzie jest uzależniona od ich wysokości, a nie od jakości świadczonych przez autoryzowanych doradców usług (tab. 8).

\section{Tabela 8}

Wyniki testów współzależności kosztów ponoszonych przez emitentów NewConnect a oceną $\mathrm{AD}$, animatorów, GPW oraz KDPW

\begin{tabular}{|l|c|c|c|c|}
\hline \multicolumn{1}{|c|}{ Badana współzależność } & $\begin{array}{c}\text { Spear- } \\
\text { man } \boldsymbol{R}\end{array}$ & $\boldsymbol{t}$ & $\boldsymbol{p}$ & $\boldsymbol{N}$ \\
\hline Koszty ponoszone na rzecz AD a ocena AD & 0,21 & 1,38 & 0,17 & 46 \\
\hline Koszty NewConnect ogółem a ocena AD & 0,18 & 1,36 & 0,18 & 59 \\
\hline $\begin{array}{l}\text { Koszty ponoszone na rzecz animatorów } \\
\text { a ocena animatorów }\end{array}$ & $-0,02$ & $-0,23$ & 0,82 & 73 \\
\hline
\end{tabular}


cd. tab. 8

\begin{tabular}{|l|c|c|c|c|}
\hline $\begin{array}{l}\text { Koszty NewConnect ogółem a ocena } \\
\text { animatorów }\end{array}$ & 0,08 & 0,70 & 0,48 & 73 \\
\hline $\begin{array}{l}\text { Koszty NewConnect ogółem a ocena } \\
\text { współpracy z GPW }\end{array}$ & $-0,11$ & $-0,97$ & 0,33 & 73 \\
\hline $\begin{array}{l}\text { Koszty NewConnect ogółem a ocena } \\
\text { współpracy z KDPW }\end{array}$ & $-0,01$ & $-0,07$ & 0,94 & 73 \\
\hline
\end{tabular}

Źródło: opracowanie własne

\section{PODSUMOWANIE}

W przeprowadzonym badaniu większość spółek uznała koszty obecności na NewConnect za zbyt wysokie, przy czym negatywne postrzeganie kosztów zwiększa się wraz z ich wysokością. Negatywne postrzeganie wysokości kosztów obecności na NewConnect może świadczyć o ich nieadekwatności w stosunku do oczekiwań ze strony notowanych spółek. Biorąc pod uwagę wyniki ankiet, w mniejszym zakresie dotyczyć to może oczekiwań dotyczących jakości pracy autoryzowanych doradców, którzy stanowią istotny koszt obecności spółek na „małej” giełdzie. Także generalnie to nie wielkość pozyskanego kapitału decyduje o negatywnym postrzeganiu kosztów obecności na NewConnect ${ }^{19}$.

Na podstawie analizy wyników przeprowadzonej ankiety można przyjąć, że negatywne postrzeganie kosztów związane jest $\mathrm{z}$ funkcjonowaniem samego rynku. Potwierdza to odpowiedź na zadane w ankiecie pytanie dotyczace realizacji zakładanych przed wejściem na NewConnect celów. Ważną informacją uzyskaną w toku badania jest to, że mimo iż tylko 2 spółki spośród badanych uznały, że nie zrealizowały swoich celów, to aż 24 (ok. 1/3) z nich nie powtórzyłoby decyzji o upublicznieniu. Spółki uzasadniały najczęściej swoją odpowiedź, poza wysokimi kosztami, przede wszystkim dużą ilością obowiązków wynikająca z faktu bycia spółką giełdowa. Sporadycznie wymienione zostały też inne czynniki z tym powiązane: nadmierna biurokracja, skomplikowane procedury, „niewspółmierna do polskich realiów” odpowiedzialność karna czy zbytnia otwartość, która może być wykorzystana przez konkurencję. Druga grupa czynników powodujących niezadowolenie emitentów jest związana ze złą koniunkturą giełdową w ciagu kilku lat przed badaniem oraz w czasie

19 Dodatkowo przeprowadzone badania wykazały zwiększenie negatywnego postrzegania kosztów obecności na NewConnect wśród spółek, które weszły na rynek po jego reformie w 2013 r. (14 z 18 spółek, czyli 78\% z nich uznało koszty za zbyt wysokie) w porównaniu ze spółkami, które zadebiutowały w latach 2007-2012 (36 na 55 spółek, 65\%, uznało je za zbyt wysokie). Czynnik czasu debiutu mógł mieć wpływ na postrzeganie kosztów obecności na NewConnect, jednak trzeba mieć na uwadze, że reforma rynku zbiegła się kontynuacją trendu spadkowego indeksu NCIndex, który zakończył się dopiero na przełomie 2018 i 2019 r. W związku z powyższym trudno jest wykazać jej związek z oceną kosztów przez emitentów. 
badania $^{20}$. Przekładała się ona na niskie wyceny oraz niskie obroty, co podkreślali emitenci, którzy nie powtórzyliby decyzji o wejściu na NewConnect.

Spółki notowane na NewConnect są najlepszymi ambasadorami tego rynku. Giełdzie powinno zależeć na ich satysfakcji z faktu bycia spółką giełdową. Zmiany w Regulaminie ASO w 2019 r., wprowadzające z jednej strony m.in. opłaty dla autoryzowanych doradców na rzecz GPW, ale z drugiej - premiujace aktywnych doradców, miały na celu podwyższenie jakości usług oferowanych przez nich usług. Z tego powodu, jak również z faktu znacznego zmniejszenia się liczby autoryzowanych doradców na polskim rynku, obniżenie kosztów obecności na NewConnect wydaje się trudne ${ }^{21}$. Nie należy spodziewać się także mniejszej ilości obowiązków wobec implementacji w polskim porządku prawnym unijnej dyrektywy MIFID II. Organizator rynku nie ma też wpływu na koniunkturę giełdowa, a ma ona niewątpliwy wpływ na odczucia emitentów. Dobra koniunktura oznacza bowiem większe zainteresowanie inwestorów, wyższe wyceny i obroty, co ułatwia przeprowadzanie nowych ofert, uzyskiwanie lepszych parametrów w operacjach M\&A, czy sprzedaż akcji przez właścicieli. Zdaniem autorów artykułu istnieje jednak sposób na to, ażeby wpłynąc na postrzeganie kosztów obecności na rynku NewConnect przez emitentów. Ważnym krokiem była wspomniana wyżej zmiana w regulacjach ASO zmierzająca do większej profesjonalizacji autoryzowanych doradców. Biorąc jednak pod uwagę, że postrzeganie kosztów obecności na giełdzie jest najbardziej negatywne w grupie spółek, które pozyskały najmniej kapitału (poniżej $1 \mathrm{mln}$ zł) oraz to, że wiele z tych spółek nie radzi sobie najlepiej na giełdzie, co potwierdza duży ich udział w wykluczeniach z obrotu giełdowego (upadłości, niewypełnianie obowiązków informacyjnych, w tym brak publikacji sprawozdań finansowych), bardzo ważnym w percepcji rynku przez spółki, inwestorów oraz media jest dbałość o jakość spółek dopuszczanych na rynek NewConnect przez jego organizatora, czyli GPW w Warszawie. W szczególności w przypadku spółek, które przeprowadzają większe emisje akcji o wartości co najmniej kilku milionów złotych, stosunek kosztów obecności na NewConnect do pozyskanej kwoty będzie korzystniejszy, co wraz z poprawą koniunktury na rynku kapitałowym będzie mogło mieć pozytywny wpływ na postrzeganie kosztów bycia spółką giełdową przez emitentów, co powinno przełożyć się również na lepsze postrzeganie całego rynku NewConnect i zwiększenie liczby debiutów.

Aczel, A.D., Sounderpandian, J. (2018). Statystyka w zarządzaniu. Warszawa: PWN.

Bernat, A.K. (2015). Luka finansowa w sektorze mikro, małych i średnich przedsiębiorstw na przykładzie województwa świętokrzyskiego. Warszawa: CeDeWu.

${ }^{20}$ W latach 2011-2018 indeks rynku NewConnect NCIndex obniżył swoją wartość o ok. 70\%, a od swojej maksymalnej wartości z początku 2008 r. - o ponad 85\%.

${ }^{21}$ Ponieważ wyniki badań pochodzą sprzed 2019 r. oraz wobec poprawy koniunktury skutkującej nie tylko zwiększeniem wartości indeksów, ale również liczbą debiutujących na NewConnect spółek autorzy będą kontynuowali swoje badania w celu sprawdzenia wpływu tych zmian na postrzeganie kosztów obecności spółek na polskim ASO. 
Gołda, E., Kowalczyk, I., Nędzi, D. (2019). Finansowanie działalności przedsiębiorstw poprzez rynek NewConnect. Studia Ekonomiczne, Prawne i Administracyjne 1: 65-80.

Homa, M., Mościborska, M. (2016), Monotoniczność premii za ryzyko inwestycji w spółki notowane na NewConnect w oparciu o trójczynnikowy model Famy-Frencha. Finanse, Rynki Finansowe, Ubezpieczenia 82(2): 133-145.

Kruk, M., Sobczak, L. (2019). Finansowanie przedsiębiorstw o wysokim potencjale wzrostu przez NewConnect, [w:] L. Gąsiorkiewicz, J. Monkiewicz (red.), Wyzwania współczesnych rynków finansowych. Management Science Series. Vol. 8. Warszawa: Politechnika Warszawska.

Kordela, D. (2012). Ocena inwestycji na NewConnect na podstawie płynności rynku i stopy zwrotu z akcji. Annales Universitatis Mariae Curie-Skłodowska. Sectio H. Oeconomia 1: 347-358.

Kordela, D. (2013). NewConnect - rynek giełdowy dla małych i średnich przedsiębiorstw. Systematyka, organizacja, perspektywy rozwoju. Warszawa: CeDeWu.

de Leeuw, E.D. (2012). Counting and Measuring Online: The Quality of Internet Surveys. Bulletin de Methodologie Sociologique 114: 68-78.

Lopez-de-Silanes, F., McCahery, J.A., Schoenmaker, D., Stanisic, D. (2019). Estimating the financing gap of small and medium-sized enterprises. Journal of Corporate Finance Research 12(2): $1-54$.

Mącik, R., Korba, M. (2010). Wiarygodność pomiaru w badaniach mixed-mode: porównanie efektów stosowania PAPI i CAWI, [w:] K. Mazurek-Łopacińska (red.), Badania marketingowe nowe wyzwania. Prace Naukowe Uniwersytetu Ekonomicznego we Wrocławiu 96: 199-210.

OECD (2006). The SME Financing Gap. Theory and Evidence. <https://ec.europa.eu/growth/content/sme-financing-gap-theory-and-evidence-vol-1-0_nn> [dostęp: 10.09.2020].

Pastusiak, R. (2010). Efektywność inwestycji na rynku NewConnect w świetle wybranych czynników. Zeszyty Naukowe Uniwersytetu Szczecińskiego. Finanse, Rynki Finansowe, Ubezpieczenia 29: 73-80.

Rymarczyk, J. (2019). Publiczne notowanie akcji jako źródło finansowania małych i średnich przedsiębiorstw. Środkowoeuropejskie Studia Polityczne 1: 155-170.

Storey, D.J. (1996). Understanding the Small Business Sector. London: Routledge.

Szczepankowski, P. (2010). Efektywność wzrostu i rozwoju spółek NewConnect w ujęciu sektorowym. Współczesna Ekonomia 13: 79-96.

Śliwiński, P., Krawiec, J., Nowak, T. (2018). Czy jest miejsce dla bodźców podatkowych dla przedsiębiorstw z sektora MŚP w rozwoju jakościowym rynku NewConnect? Studia i Materiały/ Wydział Zarządzania. Uniwersytet Warszawski 1, cz. 1: 23-36.

Wieczorek-Kosmala, M., Błach, J., Trzęsiok, J. (2020). Comparative study of the relevance of equity financing in European SMEs. Journal of Business Economics and Management 21(6): $1543-1560$.

WFE (2017). SME Financing and Equity Markets, <https://www.world-exchanges.org/home/ index.php/news/world-exchange-news/world-federation-ofexchanges-publishes-report-into-sme-financingequity-markets> [dostęp: 4.09.2020].

Woś, S. (2018). Możliwości pozyskania kapitału udziałowego przez małe i średnie przedsiębiorstwa na europejskich rynkach giełdowych, [w:] B. Stępień (red.). Zarządzanie międzynarodowe $-\mathrm{z}$ perspektywy polskich przedsiębiorstw. Poznań: PWE.

Zygmanowski, P. (2017). Determinanty rozwoju rynku akcji NewConnect. Warszawa: CeDeWu.

Zygmanowski, P., Śliwiński, P. (2019). Proposal of Indicators Measuring the Development of Companies Qualified to the NewConnect Focus Segment. Problemy Zarządzania 17(3): 197-211.

\section{THE COSTS OF A COMPANY'S PRESENCE ON THE NEWCONNECT MARKET AND ITS PERCEPTION BY ISSUERS}

\section{Sum mary}

The aim of the article is to analyse the costs of companies' presence on NewConnect and to examine its perception by issuers listed on this market. The hypothesis tested in the article states that companies consider the costs of being listed on the NewConnect market as high. This can limit the development of NewConnect, through negative perception of this market directly by is- 
suers, and also indirectly by investors and the media. The hypothesis was verified with the use of a survey conducted among companies listed on the NewConnect market. In the survey, over $70 \%$ of companies considered the cost of being listed on NewConnect to be too high. Considering that the attitude to the costs of being listed is the most negative in the group of companies that have raised the least capital (less than PLN1 million), it is very important for the perception of the market that attention is paid to the quality of companies admitted to the NewConnect market by its organizer: the Warsaw Stock Exchange in Warsaw. In particular, in the case of companies that will carry out larger (i.e. several million PLN) issues of shares, the ratio of the cost of presence on NewConnect to the amount raised will be more favourable, which, together with the improvement in the stock market conditions, should improve the market assessment by issuers.

Keywords: NewConnect; listing and being listed costs; SMEs; capital market 
